\title{
EMPIRICAL REVIEW OF FACTORS AFFECTING BUYING BEHAVIOR IN HEI'S OF KHYBER PAKHTOONKHWA PROVINCE (PAKISTAN)
} Amanullah Khattak ${ }^{1 *}$, Muhammad Imran Shah ${ }^{2}$, Adnan Khan ${ }^{3}$, Najaf Ali Shah ${ }^{4}$

${ }^{1 * 3,3,4}$ Department of Business Administration, Gomal University, Dera Ismail Khan, Pakistan; ${ }^{2}$ Department of Commerce, Gomal University, Dera Ismail Khan, Pakistan.

Email: ${ }^{1 *}$ amanu_khattak@hotmail.com, ${ }^{2}$ imranabc77@gmail.com, ${ }^{3}$ adnankhan@gu.edu.pk, ${ }^{4}$ najafshah@gu.edu.pk Article History: Received on $14^{\text {th }}$ June 2021, Revised on $23^{\text {rd }}$ June 2021, Published on $28^{\text {th }}$ June 2021

\section{Abstract}

Purpose of the study: The purpose of this study was to highlight factors that affect buying practices in higher education institutions.

Methodology: A questionnaire was used to collect primary data from respondents of higher education institutions of Khyber Pakhtunkhwa (Pakistan). Correlation \& Regression tests were applied with the help of SPSS for checking association and cause and effect relationship between predictors and criterion variables.

Main findings: Findings of the study reveal that institutional goals, objectives, policies \& procedures regarding the purchase, relationship with the suppliers \& their credibility, product knowledge, and intangibility are some key factors that affect the buying behavior of individuals in institutions.

Applications of the study: Study will help institutional buyers in particular and others in general to reduce brand sensitivity \& risk associated with the purchase by following established procedures and policies. The study will help marketers in devising corporate and marketing strategies in different environments to overcome competition.

Novelty/Originality of this study: The area of institutional buying in terms of branding has been largely ignored by researchers and academicians previously due to which this area remained underdeveloped theoretically. The study reveals the importance of various factors in institutional buying context and knowledge of these factors will help institutional buyers in particular and others in general, in reducing risk and uncertainty, by overcoming the complexity involved in institutional buying patterns.

Keywords: Higher Education Institutions, Institutional Buying, Buying Behavior, Positivism.

\section{INTRODUCTION}

Buying behavior refers to various decisions taken by individuals and businesses for buying goods and services to meet their needs. Institutional buying is a recurring activity undertaken with the aim to meet institutional needs. It engages individuals from top management to lower management because of the complexity involved in institutional purchases. Different factors need to be taken into account to ensure efficient and effective buying practices (Webster \& Wind, 1972). Higher educational institutions have been playing a key role in disseminating knowledge in the country by positively influencing its growth, provide help for better education policies, enable people for sharpening their skills and make their living better than ever (Castells, 1994; Milligan, Moretti \& Oreopoulos, 2003). The educational system is facing many ills whereas in Pakistan higher education is improving at the cost of primary education where educational budgets are inadequate (Memon, 2007). Higher education needs more attention from the state to keep it on the healthy footings by helping people to improve their education and social living towards nationality prosperity.

The educational system is facing many ills whereas in Pakistan higher education is improving at the cost of primary education where educational budgets are inadequate (Afzal, Farooq, Ahmad, Begum \& Quddus, 2010). The higher education needs more attention of the state to keep it on healthy footings by helping individuals to improve their education and social living towards the nationality prosperity. Higher education is facing new challenges due to the concept of globalization, international education, and worldwide citizenship (Kayani, Akbar, Faisal, Kayani \& Ghuman, 2017). The educational policy has been the main focus of the information age worker in the USA whereas domestic and foreign diversity are least considered. Education in the daily life domain prepares masses for interaction and provides supportive help for existence (Maia, Qoraboyev \& Gimranova, 2021). In this connection, for achieving sustainability, dissemination of knowledge and skill development should be the main aim of states to get growing better social living and economic prosperity.

\section{Problem Statement}

Institutional buying has received slight attention in terms of branding to that of consumer buying, and has been largely ignored previously by researchers and academicians due to which this area remained theoretically underdeveloped. Because of less attention in the previous literature and complexity involved in institutional buying, a need was felt to investigate determinants of buying behavior in Higher Education institutions of Khyber Pakhtunkhwa (Pakistan). 


\section{Study Objectives}

This study was conducted to explore determinants of buying behavior in Higher Education Institutions, to check the association between predictors and criterion variables, and further to check the impact of predictors on the criterion variable.

\section{LITERATURE REVIEW}

\section{Institutional Buying behavior}

Buying behavior with respect to organization and institution is indeed a complex phenomenon and cannot be easily comprehended by some factors i.e price, total cost, reciprocity, as well as ego enhancement rather there must be a complete model to deal with the complexity of organizational buying decisions involving many people (users, deciders, influencers, and buyers) with technical nature, are made over long periods of the time and require complex interaction of the personal, interpersonal, organizational, and environmental factors for determining the buyer response (Webster \& Wind, 1972). Institutional buying is the task of engaging individuals from top management and other sections of the institution. Buyer behaviors in institutions differ because of the level of risk associated with purchase situations for the rapid decision making. The act of buying (goods and services) for govt. is to procure something.

Whereas to acquire something is a broader concept and covers the whole system of acquisition (i.e. getting concept; initiation; making design; concept development \& testing; getting contract; producing; logistical support; modify and dispose of supplies and/or services for satisfaction) (Robinson et al., 1967; Brand, 1972). The buying behavior has a significant impact on intentions in the purchase of various items for use in a professional environment that need further investigation to take the decision. Institutional procurement engages individuals from top management and other sections of the institution because of the risk associated with purchase situations in rapid decision-making in particular situations. The procurement process consists of certain stages in institutional buying i.e: identifying needs and suppliers, supplier communication (RFQ, RFP, RFI \& RFT), negotiation, supplier relationship, managing logistic support, and tendering (Robinson, Faris \& Wind, 1967).

\section{Organizational Factors}

Institutional members are buying center members, who acquire goods and services in a certain process, where buying roles remain the same whereas participants do change (Robinson et al., 1967). Buying center is consisting of different people for different purchases instead of an identified unit. At times one individual may represent the entire buying role in some purchases whereas in other cases buying center may be the larger unit with many individuals (Kotler \& Armstrong, 2008). Buying center includes all the individuals who are part of the buying network. The people and departments being parts of the system perform information functions processing and communication that help in developing a system for work (Schroder et al., 1966). Structured procedures with regard to purchases will offset the psychological risk of high intensity and buying center members feel a low risk and pursue clear decision making (Newall, 1977). Procedural control may consist of a formal system (procedural guide book \& standard vendor list) or an informal system (rule of thumb principle) (Johnston and Lewin, 1994). Buying situations and the business buyers determine circumstances for brand repute that might be a significant factor in purchase decision (Mudambi 2002). Procedural control has a key role in guiding for purchase evaluation in terms of well-set policies; methods and practices (Hunter et al., 2006).

\section{Buying Situational Factors}

Institutional buyer sensitivity in naming products or services may be affected by situational factors with respect to purchasing (i.e. importance \& complexity of purchases; newness; time limitation etc.) (Sheth, 1973). The powerful factors of buying decision process are newness of the purchase situation with respect to the complexity \& importance of the purchase (Johnston and Bonoma 1981). Buyers rely more on branded products because of the involvement of perceived risk in purchases (Valla, 1982). Purchase importance is "the impact of purchase on organizational profitability and productivity". The complexity of the situation and that of the product are the two studied areas by researchers in business buying settings. The complexity of the purchase is, how much information the organization must gather to make an accurate evaluation of the product? The newness of product purchase affects the consumer level of perceived risk (McQuiston, 1989). The importance of branding increases with the increase in the complexity of buying situations (Bendixen et al., 2004).

\section{Product Factors}

In institutional buying buyer judgments are affected by the integrity of reputable organization concerning complex products and materials. Source credibility dominates other factors and helps consumers in deciding about going for or rejecting a new product where risk consequences are high (Levitt, 1967). Products \& services hold variation in the degree of intangibility due to which services carry high intangibility comparing to commodities. A positive correlation exists between intangibility and purchase risk (McDougall \& Snetsinger, 1990; Laroche et al., 2004). In the buyer-seller relationship 'corporate brands' play, a key role due to company repute, and relationships between the parties are affected positively because of long-term interaction (Chernatony, 1998). Product performance is the core of brand value whereas 
supply or distribution presentation denotes easy ordering and speedy delivery (Mudambi et al., 1997). The corporate identity of vendors is the main concern of business buyers in buying specific products (de Chernatony and McDonald, 1998). The corporate repute of a firm is difficult for competitors in terms of imitation and further, it boosts value without regarding the market (Grant, 1986; and Michell et al., 2001). The brand name signifies the company name in the institutional and organizational setup (Shipley and Howard, 1993; Michell et al., 2001).

\section{Individual Factors}

In the Institutional buying context, decisions are not made by one person rather a group of individuals and interpersonal factors become part of the decision-making process in organizations. Individual buying behavior is affected by individual characteristics like income, education, age, etc. Certain interpersonal factors like power, position, relations also affect the institutional buying process due to the involvement of more than one person in the buying process (Kotler \& Armstrong, 2008). Brand knowledge is defined as all brand-related information of descriptive and evaluative nature in consumer memory. Buyers with more product information and in-depth understanding regarding various brands are quick enough ineffective brand evaluation and quality resolve (Anderson, Engledow, \& Becker, 1980). Buyer product knowledge must talk about product awareness and individual capability while buying. Knowledgeable buyers use product quality as a base for evaluating purchases and hardly get inclined by price (Laroche, Bergeron \& Goutaland, 2003; Baker, Hunt, \& Scribner, 2002). Innovative firms are considering benchmarks for comparison with counterparts who are less on innovation (Massini et al., 2005). Because of the risk involved in institutional buying, certain areas i.e. relationship of buying and selling firms, placement of service, etc., may be affected (Webster and Keller, 2004) whereas Knowledge, risk perception, and risk attitude of buyers play important role in decision-making process when buying store brands and national brands (Erdem et al., 2004).

\section{Theoretical Framework}

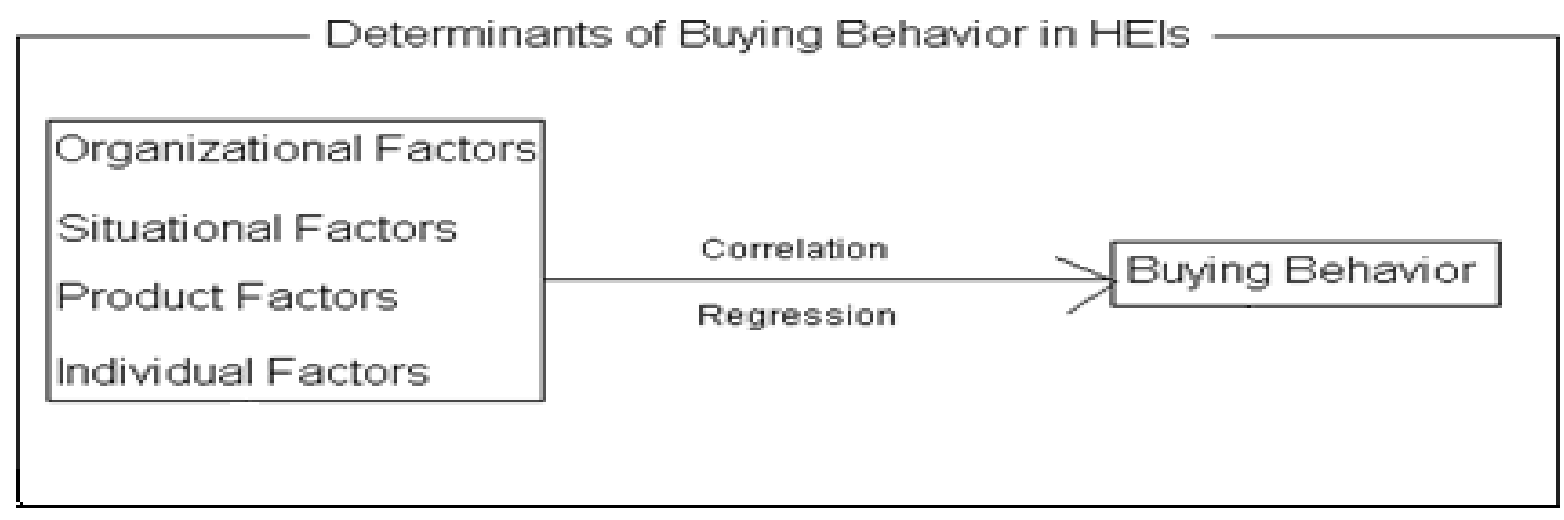

Figure 1: Showing relationship between predictors, criterion, and demographic variables

Source: Author's

\section{Research Hypothesis}

1. There is a significant relationship between predictors and criterion variables.

2. All the predictors have a significant impact on the criterion variable.

\section{METHODOLOGY}

The philosophy used in this study was positivism (a combination of doxology and epistemology). The study conducted was exploratory and descriptive in nature. The census approach was used for collecting primary data (quantitative) with the help of a self-administered questionnaire (adapted) on a five-point Likert scale, from the respondents of HEIs in Khyber Pakhtunkhwa (Pakistan) and was analyzed with the help of SPSS for checking correlation and association between different variables. Adapted scales was used for measuring buying behavior organization factors (Barclay, 1991; Hunter et al., 2006), situational factors (cannon and Perrault, 1999), product factors (Laroche et al., 2004) and individual factor (Donthu \& Gilliland, 1996; Donthu \& Garcia, 1999). Scale reliability was checked with 'Cronbach Alpha', giving an average value of 0.863 (average) for different factors. For checking normality of data different tests are used and among these Kolmogorov-Smirnov (K-S) and Shapiro-Wilk tests, which are the most popular ones. The population of the study was purchase committee members (officers/managers) of Higher Education Institutions in the province Khyber Pakhtunkhwa (Pakistan). As the population of this study was finite therefore census approach was used for collecting data. Responses of 130 respondents were collected with $86 \%$ response rate.

\section{ANALYSIS \& DISCUSSION}

\section{Correlation Analysis}

H1: All the predictors are significantly correlated with the criterion variable. 
The below table shows that Predictors are correlated with the criterion variable.

Table 1: Correlation

\begin{tabular}{|c|c|c|c|c|c|c|}
\hline & & $\begin{array}{l}\text { Organization } \\
\text { al factors }\end{array}$ & $\begin{array}{l}\text { Situationa } \\
\text { I factors }\end{array}$ & $\begin{array}{l}\text { Product } \\
\text { factors }\end{array}$ & $\begin{array}{l}\text { Individua } \\
\text { I factors }\end{array}$ & Buying behavior \\
\hline \multirow{3}{*}{$\begin{array}{l}\text { Organizational } \\
\text { Factors }\end{array}$} & Pearson Correlation & 1 & & & & \\
\hline & Sig. (2-tailed) & & & & & \\
\hline & $\mathrm{N}$ & 130 & & & & \\
\hline \multirow[t]{3}{*}{ Situational Factors } & Pearson Correlation & $.275^{* *}$ & 1 & & & \\
\hline & Sig. (2-tailed) & .002 & & & & \\
\hline & $\mathrm{N}$ & 130 & 130 & & & \\
\hline \multirow[t]{3}{*}{ Product Factors } & Pearson Correlation & $.416^{* *}$ & $.455^{* *}$ & 1 & & \\
\hline & Sig. (2-tailed) & .000 & .000 & & & \\
\hline & $\mathrm{N}$ & 130 & 130 & 130 & & \\
\hline \multirow{3}{*}{ Individual Factors } & Pearson Correlation & $.445^{* *}$ & $.392^{* *}$ & $.368^{* *}$ & 1 & \\
\hline & Sig. (2-tailed) & .000 & .000 & .000 & & \\
\hline & $\mathrm{N}$ & 130 & 130 & 130 & 130 & \\
\hline \multirow[t]{3}{*}{ Buying Behavior } & Pearson Correlation & .630 & $.293^{* *}$ & $.454^{* *}$ & $.626^{* *}$ & 1 \\
\hline & Sig. (2-tailed) & .000 & .001 & .000 & .000 & \\
\hline & $\mathrm{N}$ & 130 & 130 & 130 & 130 & 130 \\
\hline
\end{tabular}

\section{Regression Analysis}

$\mathrm{H} 2$. Buying behavior is determined by all the predictors.

Table is showing the model summary of regression analysis.

Table 2: Model summary of Regression Analysis

\begin{tabular}{lllll}
\hline Model & $\mathbf{R}$ & R Square & Adjusted R Square & Std. Error of the Estimate \\
\hline 1 & $.454^{\mathrm{a}}$ & .206 & .200 & .76723 \\
\hline 2 & $.485^{\mathrm{b}}$ & .235 & .223 & .75595 \\
\hline 3 & $.524^{\mathrm{c}}$ & .274 & .257 & .73926 \\
\hline \multicolumn{2}{l}{ a. Predictors: (Constant), product factors } \\
\hline \multicolumn{2}{l}{ b. Predictors: (Constant), product factors, individual factors } \\
\hline \multicolumn{2}{l}{ c. Predictors: (Constant), product factors, individual factors, organizational factors } \\
\hline
\end{tabular}

The below table is showing the Coefficients of Regression.

Table 3: Coefficients (included variables)

\begin{tabular}{|c|c|c|c|c|c|}
\hline \multirow{2}{*}{\multicolumn{2}{|c|}{ Model }} & \multicolumn{2}{|c|}{ Unstandardized Coefficients } & \multirow{2}{*}{$\begin{array}{l}\text { Standardized Coefficients } \\
\text { Beta }\end{array}$} & \multirow{3}{*}{$\frac{\text { T Sig. }}{6.830 .000}$} \\
\hline & & \multirow{2}{*}{$\begin{array}{l}\text { B } \\
2.970\end{array}$} & \multirow{2}{*}{$\begin{array}{l}\text { Std. Error } \\
.435 \\
\end{array}$} & & \\
\hline 1 & (Constant) & & & & \\
\hline & product factors & .506 & .088 & .454 & 5.766 .000 \\
\hline 2 & (Constant) & 2.158 & .565 & & 3.820 .000 \\
\hline & Product Factors & .430 & .093 & .386 & 4.629 .000 \\
\hline & Individual Factors & .220 & .100 & .184 & 2.202 .029 \\
\hline 3 & (Constant) & 2.345 & .557 & & 4.208 .000 \\
\hline & Product Factors & .225 & .095 & .454 & 5.300 .010 \\
\hline & Individual Factors & .313 & .104 & .262 & 3.012 .003 \\
\hline & Organizational Factors & .506 & .086 & .232 & 2.607 .000 \\
\hline
\end{tabular}

a. Dependent Variable: buying behavior 
The above table 1 is showing a correlation between predictors (Organizational Factors, Situational Factors, Product Factors, and Individual Factors) and a criterion variable (Buying Behavior). The table shows that predictors i.e: Organizational Factors (0.000), Product Factors (0.000), and Individual Factors (0.000) are highly and positively correlated with criterion variables (Buying Behavior) at p-value less than 0.05 . However, in the case of situational factors the correlation is positive but weak ( $\mathrm{r}=0.293$ with $\mathrm{p}$-value 0.001$)$. Hence it can be concluded that hypothesis\# 1 regarding correlation among research variables is fully substantiated and accepted. Table (2) is showing summary results of three regression models giving different combinations of factors predicting the buying behavior. Here in this table, all the models are significant with p-value less than 0.05 , however, the third model is the best fit model that shows the highest impact $\left(R^{\wedge} 2=0.274\right)$ of predictors on buying behavior.

Table 3 is showing the Coefficient of Regression with included variables having p-value less than 0.05 . It can be seen from the table 3 that the third model is having a greater number of variables (3) i.e. organizational factors at (b-value $0.506 \&$ p-value 0.000 ), product factors at (b-value $0.225 \&$ p-value 0.010 ), individual factors at (b-value $0.313 \& \mathrm{p}$ value 0.003$)$ that predict the buying behavior of individuals at P-value less than $(0.05)$ in higher education institutions in Khyber Pakhtoonkhwa by bringing $28 \%$ change in buyers attitude. These findings are in line with the previous research i.e: (Barclay, 1991; Hutton, 1997; Mudambi, 2002; \& Hunter et al.,2006), (Anderson and Narus, 1990; Gordon et al.., 1993; Heide and Weiss, 1995; Blomback, 2005; \& Brassington and Pettit, 2006), and (Alba and Hutchinson, 2000; Wang, 2001; Baker, Hunt, and Scribner, 2002; Lin and Zhen, 2005; \& Massini et al., 2005) respectively. Hence hypothesis \#2 regarding the prediction of the buying behavior (criterion) by the predictors, is fully supported and substantiated, hence accepted.

\section{CONCLUSION}

Research is an effort to answer specific research questions through the procedure of hypothesis testing. Analysis of the study confirms that there is a positive and significant relationship among the research variables and further from regression results, it is concluded that three predictors (organizational, product, and individual factors) predict buying behavior of individuals in higher education institutions of Khyber Pakhtoonkhwa. In light of study findings, marketers need to work on branding efforts by considering it as an important element of their marketing strategies and keep it as the central component of their overall corporate strategies. Marketers must understand institutional buyer buying behavior and should consider various factors while devising strategies for branding efforts in different business environments. This study has adopted measures of buying attitudes and applied them in institutional buying settings and seems to be versatile enough in capturing attitudes of buying officers/managers when they make or intending to decide on product selection. The institutional buyers should follow established procedures for reducing brand sensitivity and risk associated with the purchase. Institutional management should work for the solution of these issues to make institutional performance more credible. For quick and effective brand evaluation and quality determination, institutional buyers must have enough product-related information and an in-depth understanding of the different brands to make purchase decisions more productive.

\section{LIMITATIONS OF STUDY}

Invalidating buyer buying attitude in institutional buying practices, promising steps have been taken, even though this study is not without its limitations.

The questionnaire of the study didn't ask respondents to react to a specific product category that could lead to new insights by reducing noise.

In this study, the hypothesized relationships could have been significantly altered by adding mediators or moderators.

\section{SUGGESTIONS FOR FUTURE RESEARCH}

The study model can be applied in different phases of the buying process, services settings, and at particular industries.

The focus of this study was to check the buyer's perspective in institutional settings; whereas a seller's perspective can be checked in business settings, services, etc.

Research opportunities can be created by studying tangible factors of a marketer's offerings for increasing its effectiveness.

\section{AUTHORS' CONTRIBUTION}

Dr.Amanullah and Imran Shah performed manuscript drafting and statistical analysis while

Dr. Adnan Khan and Najaf Ali worked on interpretations and arrangements of technical parts.

\section{REFERENCES}

1. Afzal, M., Farooq, M. S., Ahmad, H. K., Begum, I., \& Quddus, M. A. (2010). Relationship Between School Education and Economic Growth in Pakistan: ARDL Bounds Testing Approach to Cointegration. Pakistan Economic and Social Review, 48(1), 39-60. 
2. Alba, J. W., and Hutchinson, J. W. (2000). Knowledge Calibration: What Consumers Know and What They Think They Know. Journal of Consumer Research, 27(2), 123-157. https://doi.org/10.1086/314317

3. Anderson, J. C., and James, A. N. (1990). A Model of Distributor Firm and Manufacturer Firm Working Partnerships. Journal of Marketing, 54, 42-58. https://doi.org/10.1177/002224299005400103

4. Anderson, R. D., Engledow, J. L., and Becker, H. (1980). Evaluating the Relationships Among Attitude Toward Business, Product Satisfaction, Experience, and Search Effort. Journal of Marketing Research, 16(3), 394-400. https://doi.org/10.1177/002224377901600312

5. Baker, T., Hunt, J. B., and Scribner, L. L. (2002). The Effect of Introducing A New Brand on consumer Perceptions of Current Brand Similarity: The Roles of Product Knowledge and Involvement. Journal of Marketing Theory and Practice, 10(4), 45-57. https://doi.org/10.1080/10696679.2002.11501925

6. Barclay, D. W. (1991). Interdepartmental Conflict in Organizational Buying: The Impact of the Organizational Context. Journal of Marketing Research, 28, 145-159. https://doi.org/10.1177/002224379102800203

7. Bendixen, M., Bukasa, K. A., and Abratt, R. (2004). Brand equity in the business-to-business market. Industrial Marketing Management, 33(5), 371-380. https://doi.org/10.1016/j.indmarman.2003.10.001

8. Blomback, A. (2005). Supplier Brand Image: A Catalyst for Choice. Doctoral dissertation, Jonkoping International Business School.

9. Brand, G. T. (1972). The Industrial Buying Decision. Institute of Marketing and Industrial Market Research Ltd. London.

10. Brassington, F., and Pettitt, S. (2006). Principles of Marketing. (4 ${ }^{\text {th }}$ edition). Pearson education limited, 12-65.

11. Cannon, J. P., and Jr. Perreault, W. D. (1999). Buyer-Seller Relationships in Business Markets. Journal of Marketing Research, 36, 439-460. https://doi.org/10.1177/002224379903600404

12. Castells, M. (1994). The university system: engine of development in the new world economy. In J. Salmi \& A. M. Verspoor (Eds.), Revitalising higher education (pp. 14-40). Oxford: Pergamon.

13. De Chernatony, Leslie and Malcom McDonald (1998), Creating Powerful Brands in Consumer, Service, and Industrial Markets, $2^{\text {nd }}$ ed. Oxford, England: Butterworth Heinemann.

14. Donthu and David I. Gilliland (1996), "Observations: The Infomercial Shopper," Journal of Advertising Research, 16 (2), 69-76.

15. Donthu, Naveen and Adriana Garcia (1999), "Observations: The Internet Shopper," Journal of Advertising Research, 52-58.

16. Erdem, Y. Z., and Ana, V. (2004). Performance of Store Brands: A Cross-Country Analysis of Consumer StoreBrand Preferences, Perceptions, and Risk. Journal of Marketing Research, XLI: 86-100. . https://doi.org/10.1 509/jmkr.41.1.86.25087

17. Gordon, G. L., Cantone, R. J., and Benedetto, C. A. (1993). Brand Equity in the Business-to-Business Sector: An Exploratory Study. The Journal of Product \& Brand Management, 2(3), 4-16. https://doi.org/10.11 $\underline{08 / 10610429310046689}$

18. Grant, Mc. (1986). Culture and Consumption: A Theoretical Account of the Structure and Movement of the Cultural Meaning of Consumer Goods. Journal of Consumer Research, 13, 71-84. https://doi.org/10. 1086/209048

19. Heide, J. B., and Allen, M. W. (1995). Vendor Consideration and Switching Behavior for Buyers in HighTechnology Markets. Journal of Marketing, 59, 30-43. https://doi.org/10.1177/002224299505900303

20. Hunter, G. K., Michele, D. B., and Jr. Perreault, W. D. (2006). Interrelationships among Key Aspects of the Organizational Procurement Process. International Journal of Research in Marketing, 23, 155-170. https://doi.org/10.1016/j.ijresmar.2005.10.001

21. Hutton, J. G. (1997). A Study of Brand Equity in an Organizational-Buying Context. Journal of Product \& Brand Management, 6(6), 428-439. https://doi.org/10.1108/10610429710190478

22. Johnston, W. J., and Lewin, J. E. (1994). A Review and Integration of Research on Organizational Buying Behavior. In Working Paper Series, Report No. 94-111. Cambridge, MA, Marketing Science Institute. https://doi.org/10.1177/002224298104500312

23. Johnston, W. J., and Thomas, V. B. (1981). The Buying Center: Structure and Interaction Patterns. Journal of Marketing, 45, 143-156.

24. Kapferer, J. N., and Laurent, G. (1988). Consumer brand sensitivity: A key to measuring and managing brand equity (L. Leuthesser ed. pp. 12-15). Cambridge, MA: Marketing Science Institute.

25. Kayani, M., Akbar, R., Faisal, S., Kayani, A., \& Ghuman, A. (2017). Analysis of Socio-Economic Benefits of Education in Developing Countries: A Example of Pakistan. Bulletin of Education and Research, 39(3), 75-92.

26. Kotler, P., and Armstrong, G. (2008). Principles of Marketing (12 ${ }^{\text {th }}$ edition). Pearson Education, 636.

27. Laroche, M., Bergeron, J., and Goutaland, C. (2003). How Intangibility Affects Perceive Risk: the Moderating Role of Knowledge and Involvement. Journal of Services Marketing, 17(2), 122-140. https://doi.org/10.1108/08876040310467907

28. Laroche, M., McDougall, G. H. G., Bergeron, J., and Zhiyong, Y. (2004). Exploring how intangibility affects perceived risk. Journal of Service Research, 6(4), 373-389. https://doi.org/10.1177/1094670503262955

29. Levitt, T. (1967). Communications and Industrial Selling. Journal of Marketing, 31, 15-21. https://doi.org/10.1177/002224296703100204 
30. Lin, L. Y., and Zhen, J. H. (2005). Extrinsic product performance signaling, product knowledge and customer satisfaction: an integrated analysis - an example of notebook consumer behavior in Taipei city. Fu Jen Management Review, 12(1), 65-91.

31. Maia, C., \& Qoraboyev, I., \& Gimranova, D. (2021). Higher education contributing to local, national, and global development: new empirical and conceptual insights. Higher Education, 81, 109-127. https://doi.org/ 10.1007/s10734-020-00565-8

32. Massini, S., Arie, Y. L., and Henrich, R. G. (2005). Innovators and Imitators: Organizational Reference Groups and Adoption of Organizational Routines. Research Policy, 34, 1550-1569. https://doi.org/10.10 16/j.respol.2005.07.004

33. McDougall, G. H. G., and Snetsinger, D. W. (1990). The intangibility of services: Measurement and competitive perspectives. Journal of Services Marketing, 4(4), 27-40. https://doi.org/10.1108/ EUM0000000002523

34. McQuiston, D. H. (1989). Novelty, Complexity, and Importance as Causal Determinants of Industrial Buyer Behavior. Journal of Marketing, 53, 66-79. https://doi.org/10.1177/002224298905300205

35. Memon, G. R. (2007). Education in Pakistan: The Key Issues, Problems and the New Challenges. Journal of Management and Social Sciences, 3(1), 47-55.

36. Michell, P., King, J., and Reast, J. (2001). Brand Values Related to Industrial Products. Industrial Marketing Management, 30, 415-425. https://doi.org/10.1016/S0019-8501(99)00097-8

37. Milligan, K., Moretti, E., \& Oreopoulos. P. (2003). Does Education Improve Citizenship? Evidence From the U.S. and the U.K. National Bureau of Economic Research Working Paper No. 9584. https://doi.org/10 $.3386 /$ w9584

38. Mudambi, Doyle, P., and Wong, V. (1997). An Exploration of Branding in Industrial Markets. Industrial Marketing Management, 26, 433-446. https://doi.org/10.1016/S0019-8501(96)00151-4

39. Mudambi, S. M. (2002). Branding importance in business-to-business markets: Three buyer clusters. Industrial Marketing Management, 31(6), 525-533. https://doi.org/10.1016/S0019-8501(02)00184-0

40. Murray, K. B., and Schlacter, J. L. (1990). The impact of services versus goods on consumer's assessment of perceived risk and variability. Journal of the Academy of Marketing Science, 18(1), 51-65. https://doi.org/10.1 007/BF02729762

41. Newall, J. (1977). Industrial Buyer Behavior. European Journal of Marketing, 11(3), $166-211$. https://doi.org/10.1108/EUM0000000005008

42. Olson, J. C., and Jacoby, J. (1972). Cue Utilization in the Quality Perception Process. Proceeding of the Third Annual Conference of the Association for Consumer Research, 167-179.

43. Robinson, P. J., Faris, C. W., and Wind, Y. (1967). Industrial Buying and Creative Marketing. Boston, IL: Ally and Bacon, Inc.

44. Schroder, H., Driver, M., and Streufert, S. (1966). Human Information Processing. New York: Holt, Rinehart and Winston.

45. Sheth, J. (1973). A Model of Industrial Buyer Behaviour. Journal of Marketing, 37, 50-56. https://doi.org/10.1177/002224297303700408

46. Shipley, D., and Howard, P. (1993). Brand-Naming Industrial Products. Industrial Marketing Management, 22, 59-66. https://doi.org/10.1016/0019-8501(93)90021-X

47. Valla, J. P. (1982). The Concept of Risk in Industrial Buying Behavior. Presented at Workshop on Organisational Buying Behaviour. European Institute for Advanced Studies in Management, Brussels, December 9-10.

48. Wang, W. M. (2001). The study of virtual community and experience, internet proficiency, product knowledge and information search cost on consumer perceived risk: an example of PC game soft. Masters degree thesis, Graduate School of Business Administration, National Central University, Chungli.

49. Webster, F. E., and Wind, Y. (1972). A general model of understanding organizational buying behavior. The journal of marketing, 36(2), 12-19. https://doi.org/10.1177/002224297203600204

50. Webster, Jr., and Kevin, L. K. (2004). A Roadmap for Branding in Industrial Markets. Brand Management, 11(5), 388-402. https://doi.org/10.1057/palgrave.bm.2540184

51. Zeithaml, V. A. (1988). Consumer Perceptions of Price, Quality and Value: A Means-End Model and Synthesis of Evidence. Journal of Marketing, 52(3), 2-22. https://doi.org/10.1177/002224298805200302 